\title{
Implementasi Kebijakan Anggaran Pengembangan Kompetensi Sumber Daya Aparatur di Pemerintahan Provinsi Jambi
}

\author{
M Dianto \\ Badan Pengembangan Sumber Daya Manusia Provinsi Jambi, Jambi, Indonesia \\ Email: m.dianto61@gmail.com
}

\begin{abstract}
ABSTRAK
Penelitian ini dilatarbelakangi keinginan untuk mengetahui sejauhmana implementasi kebijakan anggaran pengembangan kompetensi aparatur di Lingkungan Pemerintah Provinsi Jambi. Tujuan penelitian ini adalah untuk mengetahui faktor-faktor yang mempengaruhi implementasi kebijakan anggaran pengembangan kompetensi aparatur oleh para Kepala Organisasi Perangkat Daerah (OPD) yang memiliki tanggungjawab untuk mengelola kebijakan teknis, program dan kegiatan pada masingmasing OPD.. Penelitian ini berbasiskan teori implementasi George C Edward III yang menyatakan bahwa implementasi dipengaruhi oleh empat variabel, yakni komunikasi, sumber daya, disposisi dan struktur birokrasi. Metode yang digunakan dalam penelitian ini ialah menggunakan metode kuantitatif dan kualitatif secara bersamaan dengan data primer dan sekunder yang diperoleh melalui wawancara mendalam, observasi dan studi dokumentasi. Informan ditentukan dengan purposive sampling, yakni para Kepala OPD. Triangulasi data dilakukan dengan metode triangulasi sumber. Hasil penelitian ini menunjukan bahwa implementasi kebijakan anggaran pengembangan kompetensi aparatur di Lingkungan Pemerintah Provinsi Jambi belum optimal hal ini ditandai dengan tersumbatnya komunikasi dimana tidak adanya transmisi komunikasi yang diterima Kepala OPD terhadap aturan anggaran 0,34\% APBD dipergunakan untuk pengembangan kompetensi aparatur. Selain itu, belum optimalnya implementasi juga disebabkan hampir sebagian besar OPD memiliki anggaran pengembangan kompetensi aparatur dibawah 0,34\%. Dampak dari tidak optimalnya kebijakan anggaran pengembangan kompetensi aparatur adalah hanya sekitar 15\% PNS di provinsi ini yang memiliki kesempatan untuk memperoleh pelatihan pengembangan kompetensinya. Walaupun demikan, kabar baiknya adalah para Kepala OPD sepakat menyatakan bahwa perlu diberi ruang bagi aparatur untuk mengembangkan kompetensinya dan mereka berjanji untuk meningkatkan anggaran pengembangan kompetensi aparatur minimal sesuai peraturan perundang-undangan yang berlaku.
\end{abstract}

Kata Kunci: Implementasi, kebijakan anggaran, kompetensi aparatur

\section{PENDAHULUAN}

Pengembangan dan peningkatan kualitas Sumber Daya Manusia Aparatur Sipil Negara (ASN) pada saat ini menjadi wacana yang mengemuka baik pada sektor publik maupun privat.. Pada sektor penyelenggaraan pemerintahan, upaya pengembangan dan peningkatan kualitas sumber daya manusia aparatur mutlak dilaksanakan guna menjawab kritik dan sorotan masyarakat terhadap akuntabilitas kinerja instansi publik dalam mewujudkan pemerintahan yang baik (good governence), sehingga dunia usaha (corporate governance) dan masyarakat (civil society) dapat terlayani dengan baik dan mampu meningkatkan pertumbuhan ekonomi dan sosial yang pada akhirnya akan meningkatkan kesejahteraan masyarakat. 
Mengacu pada peraturan perundang-undangan tentang kepegawaian, dikatakan bahwa setiap ASN berhak mendapatkan peningkatan kompetensinya setara 20 (dua puluh) Jam pelajaran setiap tahunnya. Dan jika mengacu pada Permendagri Nomor 33 Tahun 2019 tentang Pedoman Penyusunan APBD Tahun 2020, jumlah anggaran pengembangan kompetensi aparatur minimal sebesar $0.34 \%$ dari APBD. Jumlah APBD Provinsi Jambi tahun $2018 \pm$ Rp 4,5 T, $2019 \pm$ Rp 4.8 Trilyun dan $2020 \pm$ Rp 4.9 T, sehingga jika dikalkulasi 0.34\% berarti berjumlah : Rp 15,3 Milyar - Rp 16.7 Milyar seyogyanya digunakan untuk anggaran pengembangan kompetensi aparatur.

Problem utama bagi para pejabat pemerintah dalam mengimplementasikan suatu program adalah banyaknya faktor yang berpengaruh dalam pelaksanaannya, dan juga faktor waktu karena implementasi kebijakan juga dipengaruhi pada siklus anggaran pemerintah yang dibahas dengan pihak DPRD. Oleh karena itu, penulis tertarik untuk meneliti sejauhmana proses implementasi kebijakan anggaran pengembangan kompetensi sumber daya aparatur, dan dampak jangka pendek dari kebijakan anggaran pengembangan kompetensi sumber daya manusia aparatur serta mendeskripsian kendala-kendala yang mempengaruhi efektivitas kebijakan anggaran pengembangan kompetensi sumber daya manusia aparatur pada Pemerintahan Provinsi Jambi.

\section{LANDASAN TEORI}

\section{Konsep Kebijakan Publik}

Konsep lain tentang konsep kebijakan publik disajikan oleh Thomas $\mathrm{R}$ Dye yang mendefinisikan "public policy is whatever the government choose to do or not to do" (Kebijakan publik adalah apapun pilihan pemerintah untuk melakukan sesuatu atau tidak melakukan sesuatu). Menurut Dye, apabila pemerintah memilih untuk melakukan sesuatu, maka tentunya ada tujuannya karena kebijakan publik merupakan "tindakan" pemerintah. Apabila pemerintah memilih untuk tidak melakukan sesuatu, inipun merupakan kebijakan publik, yang ada tujuannya. George C. Edwards III dan Ira Sharkansky dalam Suwitri (2008:10) mendefinisikan kebijakan publik sebagai suatu tindakan pemerintah yang berupa program-program pemerintah untuk pencapaian sasaran atau tujuan. Dari dua definisi diatas kita bisa melihat bahwa kebijakan publik memiliki kata kunci "tujuan", "nilai-nilai" dan "praktik".

Dari beberapa pendapat diatas, dapat disimpulkan, kebijakan publik pada prinsipnya dibuat oleh badan/pejabat pemerintah dan ditujukan kepada kepentingan masyarakat secara luas dan wujudnya kebijakan publik dapat berupa sesuatu yang dilakukan pemerintah (to do) maupun sesuatu yang dibiarkan pemerintah (not to do). Dengan kata lain bahwa kebijakan publik merupakan suatu tindakan terencana untuk menyelesaikan persoalan/masalah bersama. 


\section{Implementasi Kebijakan}

Pendekatan model implementasi kebijakan yang berspektif top down yang dikembangkan oleh George C. Edward III. Edward III menamakan model implementasi kebijakan publiknya dengan Direct and Indirect Impact on Implementation. Dalam pendekatan teori ini terdapat empat variabel yang mempengaruhi keberhasilan impelementasi suatu kebijakan, yaitu : komunikasi; sumberdaya; disposisi; dan struktur birokrasi.

1. Komunikasi. Variabel pertama yang mempengaruhi keberhasilan implementasi kebijakan menurut George C. Edward III (dalam Agustino), adalah komunikasi. Komunikasi, menurutnya sangat menentukan keberhasilan pencapaian tujuan dari implementasi kebijakan publik. Implementasi yang efektif terjadi apabila para pembuat keputusan sudah mengetahui apa yang akan mereka kerjakan. Indikator untuk mengukur keberhasilan komunikasi adalah transmisi komunikasi, kejelasan komunikasi dan konsitensi komunikasi itu sendiri.

2. Sumber daya. Variabel kedua yang mempengaruhi keberhasilan implementasi kebijakan adalah sumber daya. Sumber daya merupakan hal penting lainnya dalam mengimplementasikan kebijakan, menurut George C. Edward III (dalam Agustino), Indikator sumber daya meliputi : staf, informasi, wewenang, dan fasilitas.

3. Disposisi. Variabel ketiga yang mempengaruhi keberhasilan implementasi kebijakan adalah disposisi. Hal-hal penting yang perlu dicermati pada variabel disposisi, menurut George C. Edward III (dalam Agustino), adalah: pengangkatan birokrat dan insentif.

4. Struktur birokrasi. Variabel keempat yang mempengaruhi keberhasilan implementasi kebijakan publik adalah struktur birokrasi.. Dua karakteristik, menurut Edward III, yang dapat mendongkrak kinerja struktur birokrasi kearah yang lebih baik, yaitu: SOP dan fragmentasi.

Di sini kebijakan yang menyangkut banyak kepentingan yang berbeda akan lebih sulit diimplementasikan dibanding yang menyangkut sedikit kepentingan. Oleh karenanya tinggi-rendahnya intensitas keterlibatan berbagai pihak (politisi, pengusaha, masyarakat, kelompok sasaran dan sebagainya) dalam implementasi kebijakan akan berpengaruh terhadap efektivitas implementasi kebijakan.

Dalam penelitian ini, keempat variabel pendekatan model Edward III ini dipakai sebagai pedoman untuk mengukur keberhasilan implementasi kebijakan anggaran yang ada. Hal ini dikarenakan keempat variabel dengan 11 (sebelas) indikator dalam model ini, peneliti anggap cocok dengan penelitian implementasi kebijakan anggaran.

\section{METODOLOGI PENELITIAN}

Jenis penelitian ialah penelitian evaluasi dengan pendekatan campuran dengan menggunakan metode kuantitatif dan kualitatif secara bersamaan baik dalam 
pengumpulan data dan analisisnya. Data yang digunakan adalah data primer dan data sekunder. Informan dalam penelitian ini ditentukan dengan purposive sampling, yakni Para Kepala OPD di Pemerintah Provinsi Jambi sebagai implementor kebijakan unit organisasi. Data Penelitian diperoleh melalui wawancara mendalam terhadap para Kepala OPD. Dan juga dilakukan observasi dan studi dokumentasi dalam rangka mendukung kevalidan data (kroscek data). Keabsahan data yang didapat diuji dengan melakukan triangulasi sumber data dan dianalisis melalui tiga tahapan yaitu reduksi, penyajian dan penarikan kesimpulan

\section{HASIL DAN PEMBAHASAN}

Penelitian ini mendeskripsikan implementasi kebijakan penganggaran program pengembangan kompetensi aparatur pada 33 OPD Lingkup Pemerintah Provinsi Jambi berbasiskan teori George C. Edward III yang meliputi 11 (sebelas) indikator yang mempengaruhi implementasi. Selanjutnya hasil dari penelitian 11 (sembilan) indikator ini penulis interpretasikan untuk menjawab pertanyaan penelitian seperti yang tertera diproposal penelitian. Hasil penelitian menunjukkan hal-hal sebagai berikut :

\section{Transmisi}

Hasil penelitian indikator trasnmisi dijumpai hal sangat esensi yang selama ini tidak diketahui, yaitu bahwa sebagian besar Kepala OPD masih belum mendapatkan informasi yang baik dan sahih terkait ketentuan anggaran pengembangan kompetensi sumber daya aparatur. Pada indikator transmisi komunikasi sebagian besar kepala OPD belum memperoleh informasi yang baik dan utuh tentang peraturan perundangundangan yang terkait dengan batasan minimal anggaran pengembangan kompetensi sumber daya aparatur dimasing-masing OPD. Kepala OPD belum memperoleh informasi (transmisi) dari pemangku kepentingan terkait dengan peraturan yang dimaksud. Hal ini sebagian besar disebabkan mereka berfokus kepada pelaksanaan tugas teknis masing-masing, sebagaimana hasil wawancara Kepala Dinas Perpustakaan dan Arsip Daerah (DPAD) Bapak Syamsurizal sebagai berikut:

“.......terkait 0,34\% APBD untuk anggaran pengembangan kompetensi aparatur...masih banyak yang belum mengetahui...." (Wawancana Senin, 13 Juli 2020 pukul 12.100 WIB tempat Kantor DPAD)

Dan hal ini diperkuat dari hasil wawancara dengan Kepala Dinas Perijinan Terpadu Satu Pintu (PTSP) Bapak Imron Rosyadi sebagai berikut:

“......terkait 0,34\% APBD untuk anggaran pengembangan kompetensi aparatur...tidak/karena tidak ada sosialisasi...."(Wawancana Selasa, 14 Juli 2020 pukul 16.30 WIB tempat Kantor PTSP) 
Dan juga hasil wawancara dengan Kepala Dinas Lingkungan Hidup (DLH) Bapak Bachyuni Deliansyah sebagai berikut:

".......terkait 0,34\% APBD untuk anggaran pengembangan kompetensi aparatur...tidak tahu...." (Wawancana Selasa, 8 september 2020 pukul 12.05 WIB tempat Kantor DLH) Dari pendapat tiga perwakilan kepala OPD tersebut diatas, tampak nyata bahwa pengembangan kompetensi aparatur tidak menjadi perhatian utama dan bahkan ada kesan Kepala OPD tidak tahu. Tidak adanya transmisi informasi ini patut disayangkan, karena para kepala OPD adalah pengambil kebijakan terkait dengan penganggaran dimasing-masing OPD. Kepedulian kepala OPD terhadap anggaran pengembangan kompetensi aparatur mereka patut juga dipertanyakan, hal ini karena para Kepala OPD ini adalah manajer sekaligus pemimpin yang sudah ikut beberapa pelatihan (diklat) yang tujuannya adalah meningkatkan kompetensinya, dan sudah pasti sudah memahami arti pentingnya kompetensi aparatur bagi bagi penciptaan organisasi berkinerja tinggi (OBT).

\section{Kejelasan}

Hasil penelitian indikator kejelasan komunikasi, sebagian besar Kepala OPD menyatakan bahwa komunikasi berjalan baik utamanya dengan Tim Anggaran Pemerintah Daerah (TPAD) dan Badan Anggaran DPRD. Dalam berkomunikasi dengan TPAD dan Banggar, Kepala OPD berfokus pada program dan kegiatan teknis masing-masing, dan terkait anggaran peningkatan kompetensi aparatur merupakan pilihan terakhir jika masih ada anggaran yang tersisa. Tampak jelas bahwa Kepala OPD menganggap anggaran peningkatan kompetensi aparatur bukan merupakan prioritas. Seperti yang disampaikan oleh Sekretaris Bappeda Bapak Ruspen yang menyatakan bahwa pernah mengalami mis-komunikasi dengan pihak stakeholders terkait penganggaran pengambangan kompetensi aparatur dan beliau juga menyatakan tidak cukup jelas saat pengambilan keputusan terkait anggaran pengembangan kompetensi aparatur sebagaimana penyataan sebagai berikut :

".......apakah sudah cukup jelas diketahui setiap akan mengambil keputusan terkait

anggaran pengembangan kompetensi aparatur...tidak cukup jelas....."(Wawancara Selasa, 14 Juli 2020, pukul : 08.50 Wib Tempat Kantor Bappeda).

Pernyataan ini didukung oleh Kepala Dinas Perijinan Terpadu dan Satu Pintu Bapak Imron Rosyadi yang menyatakan bahwa pernah mengalami mis-komunikasi dengan pihak-pihak terkait penganggaran pengembangan kompetensi aparatur, dan beliau juga menyatakan belum mengetahui dengan jelas tentang anggaran pengembangan kompetensi aparatur saat mau ambil keputusan, sebagaimana yang dinyatakan dibawah ini :

“.......apakah sudah cukup jelas diketahui setiap akan mengambil keputusan terkait anggaran pengembangan kompetensi aparatur...belum jelas....."(Wawancana Selasa, 14 Juli 2020 pukul 16.30 WIB tempat Kantor PTSP). 
Pernyataan 2 OPD tersebut diatas didukung oleh Kepala Dinas Lingkungan Hidup Bapak Bachyuni Deliansyah yang menyatakan sering terjadi mis-komunikasi saat pembahasan anggaran dengan para pihak terkait anggaran termasuk anggaran pengembangan kompetensi aparatur dan beliau juga menyatakan belum mengetahui dengan baik saat mengambil keputusan penganggaran kompetensi aparatur sebagaimana pernyataan berikut :

".......apakah sudah cukup jelas diketahui setiap akan mengambil keputusan terkait anggaran pengembangan kompetensi aparatur....belum..... (wawancana Selasa, 8 september 2020 pukul 12.10 WIB tempat Kantor DLH).

\section{Konsistensi}

Hasil penelitian indikator konsistensi komunikasi, sebagian besar Kepala OPD menyatakan bahwa komunikasi berjalan lancar dan sesuai komitmen yang ada. Belum pernah terjadi mis-komunikasi dalam pembahasan anggaran termasuk anggaran pengembangan kompetensi aparatur. Dan sebagian besar Kepala OPD menyatakan anggaran pengembangan kompetensi aparatur penting dan menganggarakan sesuai kebutuhan. Hanya saja pernyataan tersebut tidak sesuai dengan realisasi anggaran pengembangan kompetensi aparatur OPD masing-masing, dan sebagian besar masih dibawah 0,34\% sebagaimana yang diamanatkan Permendagri. Keterbatasan anggaran OPD merupakan alasan klasik dari para Kepala OPD sehingga kebutuhan anggaran pengembangan kompetensi aparatur masih belum memadai dibanding kebutuhan OPD. Tidak konsistennya Kepala OPD tampak jelas dari pernyataan mereka yang menyatakan menganggarkan program pengembangan kompetensi sumber daya aparatur sesuai kebutuhan, tetapi dipihak lain tidak menjadi prioritas sebagai yang disampaikan Kepala Dinas Pemberdayaan Perempuan dan Perlindungan Anak (DP3A) Ibu Lutpiah sebagai berikut:

".......apakah ibu menganggarakan pengembangan kompetensi sesuai kebutuhan...ya......apakah Ibu memprioritaskan pengembangan kompetensi aparatur?......tidak prioritas......... "(Wawancara Selasa, 21 Juli 2020, pukul : 08.15 wib Tempat kantor DP3A)

Pendapat ini juga didukung Sekretaris DPRD Ibu Emi Nopisah yang menyatakan bahwa sudah menganggarkan program pengembangan kompetensi aparatur sesuai kebutuhan dan belum merupakan prioritas sebagaimana pendapatnya sebagai berikut :

".......anggaran pengembangan kompetensi aparatur sudah dianggarkan sesuai kebutuhan, tetapi belum merupakan prioritas......"(Wawancara Rabu, 22 Juli 2020, pukul : 07.00 wib Tempat Sekretariat DPRD)

Dan hal ini diperkuat dengan pernyataan Kepala Badan Keuangan Daerah (Bakeuda) Bapak Agus Pirngadi sebagai berikut :

“.......apakah bapak menganggarakan pengembangan kompetensi sesuai kebutuhan...ya......apakah bapak memprioritaskan pengembangan kompetensi 
aparatur?.....prioritas "(Wawancara Senin, 3 Agustus 2020, pukul : 07.10 wib

Tempat Kantor Bakeuda).

Dari tiga indikator komunikasi yang diteliti yaitu transmisi, kejelasan dan konsistensi, indikator yang paling berpengaruh adalah transmisi, hal ini sangat krusial karena transmisi merupakan syarat awal terjadinya komunikasi itu sendiri, kemudian selanjutnya diikuti apakah ada kejelasan dalam penyampaian komunikasi itu kepada aparatur yang mengimplementasikannya dilapangan dan indikator konsistensi diperlukan agar tidak "pesan" ambigu dalam penyampaian komunikasi itu sendiri.

Secara umum OPD di Lingkup Pemerintah Provinsi Jambi tidak memperoleh informasi (transmisi) dari pemangku kepentingan khususnya terkait anggaran pengembangan kompetensi aparatur, dan hanya beberapa OPD yang memperoleh informasi tersebut dari berbagai sumber, utamanya mereka mendapat informasi tersebut dari Permendagri 33 Tahun 2019, OPD yang memperoleh informasi tersebut diantaranya Bappeda, Rumah Sakit Jiwa, Satpol PP dan Inspektorat. Jika dianalisis lebih lanjut, kejelasan komunikasi yang diperoleh para Kepala OPD merujuk pada anggaran secara umum dan tidak spesifik anggaran untuk pengembangan kompetensi aparatur. Hal ini tercermin dari jawaban-jawaban mereka yang tidak fokus dan cenderung melebar berbicara anggaran OPD secara umum. Dan pada indikator konsistensi komunikasi, walaupun sebagian besar OPD menjawab konsisten, hanya saja setelah jawaban tersebut dikomparasi dengan temuan informasi persentase anggaran pengembangan kompetensi aparatur yang disediakan pada masing-masing OPD, maka ditemukan bahwa anggaran pengembangan kompetensi aparatur pada sebagian besar OPD dibawah 0,34\%, artinya tidak ada konsistensi jawaban dan eksekusi kebijakan dilapangan.

Berdasarkan hasil penelitian dan analisis jawaban informan pada variabel komunikasi, dapat disimpulkan bahwa komunikasi antar stakeholder terkait anggaran pengembangan kompetensi aparatur di OPD Pemerintah Provinsi Jambi belum berjalan baik dan dapat dikategorikan tersumbat. Dan berakibat pada penganggaran program pengembangan kompetensi aparatur masih jauh dari ketentuan yang diamanatkan.

\section{Staf}

Dari hasil penelitian, untuk indikator sumber daya staf, sekitar 16 OPD memiliki staf yang cukup dan memiliki kemampuan untuk merencanakan dan menyusun anggaran termasuk anggaran pengembangan kompetensi aparatur. Pada tabel 7 tampak jelas 17 OPD lainnya tidak memiliki staf yang cukup dan kompetensi yang memadai untuk merencanakan dan menyusun anggaran termasuk anggaran pengembangan kompetensi aparatur, sebagaimana hasil wawancara dengan Kepala BKD Bapak Pahari sebagai berikut:

".......apakah memiliki staf yang memiliki kemampuan untuk merencanakan dan menyusun anggaran termasuk pengembangan kompetensi 
aparatur?.....ada ."(Wawancara Rabu, 22 Juli 2020, pukul : 09.00 wib Tempat Kantor BKD).

Pendapat Kepala BKD atas, disetujui oleh Kepala Dinas Kominfo Bapak Nurachmat Herlambang yang menyatakan :

“.......apakah memiliki staf yang memiliki kemampuan untuk merencanakan dan menyusun anggaran termasuk pengembangan kompetensi aparatur?.....ada bagian kasubbag program dan belum memadai jumlahnya ......."(Wawancara Rabu, 23 Juli 2020, pukul : 14.00 wib Tempat Kantor Kominfo).

Sementara 17 OPD lainnya tidak memiliki staf yang khusus berkemampuan untuk merencanakan dan menyusun anggaran pengembangan kompetensi aparatur sebagaimana yang dikemukakan oleh Direktur Rumah Sakit Jiwa Bapak Firmansyah sebagai berikut :

“.......apakah memiliki staf yang memiliki kemampuan untuk merencanakan dan menyusun anggaran termasuk pengembangan kompetensi aparatur?.....tidak ada ......"(Wawancara Rabu, 24 Juli 2020, pukul : 10.05 wib Tempat RSJ).

\section{Informasi}

Hasil penelitian sumber daya informasi, sebagian besar Kepala OPD sudah memahami dan informasi yang jelas tentang cara penyusunan anggaran OPD. Hanya saja untuk kepatuhan terhadap aturan sebanyak 19 OPD tidak patuh yaitu memiliki anggaran pengembangan kompetensi aparatur dibawah 0,34\%. Berdasarkan penuturan mereka para Kepala OPD menyatakan bahwa mereka belum memiliki informasi yang valid dan sah terkait ketentuan jumlah anggaran pengembangan kompetensi aparatur, khususnya klausul ketentuan 0,34\% APBD untuk anggaran pengembangan kompetensi aparatur. Dari indikator sumber daya informasi hanya 9 OPD yang memiliki informasi yang valid dan sahih terkait aturan Permendagri 33 Tahun 2019 khususnya pada klausul anggaran pengembangan kompetensi aparatur, 5 OPD tidak memiliki informasi jawaban yang memadai. Hasil ini menunjukkan bahwa para stakeholder yang terkait program pengembangan kompetensi aparatur perlu bekerja keras lagi untuk meningkatkan kualitas dan kuantitas informasi khususnya informasi ketentuan anggaran pengembangan kompetensi aparatur.

Dari indikator sumber daya informasi, 8 OPD memiliki informasi anggaran pengembangan kompetensi aparatur yang memenuhi ketentuan aturan, OPD tersebut adalah : BKD, BPSDM, BPAD, Bappeda, Dinas Kominfo, Dinas Koperasi UKM, RSJ dan Inspektorat. 5 OPD tidak memiliki informasi sama sekali yaitu Kesbangpol BPBD, Balitbangda, Dinas Pendidikan, dan Dinas Perindag. Dan 20 OPD lainnya memiliki anggaran pengembangan kompetensi aparatur dibawah $0,34 \%$ dari APBD nya. Masalah utama OPD terkait dengan informasi ini adalah sebagian besar belum mendapat informasi yang cukup terkait 0,34\% anggaran pengembangan kompetensi aparatur, dan OPD tidak memiliki staf khusus yang mengkaji aturan- 
aturan yang ada, sebagaimana dinyatakan Direktur RSJ Bapak Firmansyah sebagai berikut :

".......apakah sudah disampaikan informasi terkait melaksanakan kebijakan Permendagri?.......belum........"(Wawancara Jum'at, 24 Juli 2020, pukul : 10.10 wib Tempat RSJ).

Pernyataan ini didukung oleh pendapat Kepala Dinas Kesehatan Bapak Reflizar sebagai berikut :

“......apakah sudah disampaikan informasi terkait melaksanakan kebijakan Permendagri?.......sudah tetapi belum mendetail......."(Wawancara Jum;at, 24 Juli 2020, pukul : 08.30 wib Tempat Kantor Dinkes).

Sekretaris Balitbangda Ibu Eka Feriani juga mengemukakan bahwa mereka belum memiliki informasi tersebut sebagaimana pendapatnya dibawah ini :

".......apakah sudah disampaikan informasi terkait melaksanakan kebijakan Permendagri?.......belum........"(Wawancara Senin, 27 Juli 2020, pukul : 08.30 wib Tempat Kantor Balitbangda).

\section{Kewenangan}

Hasil penelitian indikator kewenangan, 14 Kepala OPD menjawab tidak memiliki kewenangan penuh saat membahas anggaran dan termasuk untuk melaksanakan pengembangan kompetensi aparaturnya, dan 19 Kepala OPD menjawab memiliki kewenangan untuk melaksanakan pengembangan komptensi aparaturnya. Berdasarkan Instruksi Gubernur (InGub) Nomor 2/INGUB/BPSDM-1.1/2018 Tahun 2018 Tentang Pengembangan Sumber Daya Manusia Secara terintegrasi di BPSDM Provinsi Jambi, kewenangan untuk melaksanakan pengembangan sumber daya aparatur dilingkungan Pemerintah Provinsi Jambi sudah dilimpahkan ke BPSDM Provinsi Jambi. Untuk OPD masih diberi kewenangan melaksanakan pengembangan kompetensi aparaturnya dengan ketentuan bukan dalam bentuk Diklat, seperti kursus, workshop, bintek yang jumlah harinya maksimal 3 (tiga) hari. Hakikatnya, semua Kepala OPD masih diberi kewenangan untuk melaksanakan pengembangan kompetensi aparaturnya, hanya saja mereka ragu dengan adanya Nomor 2/INGUB/BPSDM-1.1/2018 Tahun 2018 Tentang Pengembangan Sumber Daya Manusis Secara terintegrasi di BPSDM Provinsi Jambi.

Untuk indikator sumber daya kewenangan, 14 Kepala OPD menjawab tidak memiliki kewenangan untuk melaksanakan pengembangan komptensi aparaturnya, dan 19 Kepala OPD menjawab memiliki kewenangan untuk melaksanakan pengembangan komptensi aparaturnya. OPD yang berpendapat tidak memiliki kewenangan dalam penganggaran pengembangan kompetensi sumber daya aparatur, umumnya kuesioner dijawab oleh Sekretrais OPD sebagaimana pernyataan Sekretaris Balitbangda Ibu Eka Feriani berikut : 
“.......apakah anda punya kewenangan untuk menetapkan anggaran pengembangan kompetensi sumber daya aparatur? tidak "(Wawancara Senin, 27 Juli 2020, pukul : 08.35 wib Tempat Kantor Balitbangda).

Pendapat yang sama dinyatakan oleh Sekretaris Dinas Kelautan dan Perikanan Bapak Amar Shalahudin sebagai berikut :

“.......apakah anda punya kewenangan untuk menetapkan anggaran pengembangan kompetensi sumber daya aparatur? tidak "(Wawancara Selasa, 28 Juli 2020, pukul : 08.05 wib Tempat Kantor Dinas Kelautan dan Perikanan).

Dan didukung oleh pernyataan Kepala Dinas PTSP Bapak Imron Rosyidi sebagai berikut:

“.......apakah anda punya kewenangan untuk menetapkan anggaran pengembangan kompetensi sumber daya aparatur?........tidak........"(Wawancara Selasa, 14 Juli 2020 pukul 16.30 WIB tempat Kantor PTSP).

\section{Fasilitas}

Hasil penelitian indikator fasilitas, 24 Kepala OPD menjawab memiliki fasilitas untuk pengembangan kompetensi aparaturnya, dan 9 Kepala OPD menjawab tidak memiliki sumber daya fasilitas yang memadai untuk melaksanakan pengembangan kompetensi aparaturnya. Pernyataan Kepala DP3AP Ibu Lutfiah yang secara tersirat menyatakan :

“.......apakah OPD saudara memiliki saranda dan prasarana yang memadai untuk pelatihan pengembangan kompetensi aparatur?......tidak......... "(Wawancara Selasa, 21 Juli 2020, pukul : 08.20 wib Tempat kantor DP3AP)

Pernyataan senada disampaikan oleh Sekretatis Balibatbangda Ibu Eka Feriani sebagai berikut :

“.......apakah OPD saudara memiliki saranda dan prasarana yang memadai untuk pelatihan pengembangan kompetensi aparatur?......tidak "(Wawancara Senin, 27 Juli 2020, pukul : 08.35 wib Tempat Kantor Balitbangda)

Dan juga didukung oleh pernyataan Kepala Dinas Kominfo Bapak Nurachmat Herlambang sebagai berikut :

“.......apakah OPD saudara memiliki saranda dan prasarana yang memadai untuk pelatihan pengembangan kompetensi aparatur?......belum memadai karena kantor dinas Kominfo belum representatif......... "(Wawancara Rabu, 23 Juli 2020, pukul : 14.05 wib Tempat Kantor Kominfo))

\section{Pengangkatan Birokrat}

Pada indikator pengangkatan birokrat, para Kepala OPD menganggap peranan staf yang berkompeten sangat penting dalam menunjang kinerja organisasi. Dua faktor penting yang sangat mempengaruhi indikator ini adalah kualitas staf dan kuantitas staf. Secara kuantitas masih dijumpai beberapa OPD yang tidak memiliki staf yang cukup dalam penyusunan anggaran termasuk pengembangan kompetensi sumber 
daya aparaturnya, dan secara kualitas juga belum memiliki staf yang memadai dalam menyusun anggaran termasuk pengembangan kompetensi aparatur. Beberapa Kepala OPD beranggapan bahwa kondisi yang ada masih berjalan dengan baik dan tidak memiliki hambatan-hambatan yang nyata terhadap implementasi kebijakan, walaupun demikian Kepala OPD menyetujui bahwa mereka perlu memilki staf berdedikasi tinggi untuk melaksanakan kebijakan-kebijakan yang diinginkan oleh Kepala OPD sebagaimana yang disampaikan oleh Kepala PTSP Bapak Imron Rosyadi sebagaimana berikut :

".......apakah saudara memiliki staf yang dapat diandalkan dalam penyusunan anggaran pengembangan komptensi aparatur?........belum........"(Wawancara Selasa, 14 Juli 2020 pukul 16.35 WIB tempat Kantor PTSP).

Pendapat yang sama dikemukakan oleh Sekretaris Balitbangda Ibu Eka Feriani sebagaimana hasil wawancara berikut :

“.......apakah OPD saudara memiliki staf yang dapat diandalkan dalam penyusunan anggaran pengembangan kompetensi aparatur?......tidak......... "(Wawancara Senin, 27 Juli 2020, pukul : 08.40 wib Tempat Kantor Balitbangda).

Dan juga didukung pernyataan Direktur RSJ Bapak Firmansyah sebagai berikut :

".......apakah memiliki staf yang memiliki staf yang dapat diandalkan menyusun anggaran pengembangan kompetensi aparatur?.....tidak ......"(Wawancara Rabu, 24 Juli 2020, pukul : 10.10 wib Tempat RSJ).

\section{Insentif}

Pada indikator Insentif, untuk mengatasi masalah kecenderungan para pelaksana adalah dengan memberikan insentif khusus untuk mempengaruhi tindakan staf. Hasil penelitian menunjukkan bahwa sebagian besar Kepala OPD tidak memberikan insentif khusus untuk para stafnya, sebagaimana dikemukakan Kepala BKD Bapak Pahari sebagai berikut:

".......apakah saudara memberikan insentif khusus pada staf yang berkompeten?........belum........"(Wawancara Rabu, 22 Juli 2020, pukul : 09.05 wib Tempat Kantor BKD).

Pendapat ini didukung oleh Sekretaris Dinas Kelautan dan Perikanan Bapak Ammar Shalahudin yang menyatakan :

"...........apakah saudara memberikan insentif khusus pada staf yang berkompeten?........belum........." (Wawancara Selasa, 28 Juli 2020, pukul : 08.15 wib Tempat Kantor Dinas Kelautan dan Perikanan).

Dan pendapat yang sama dikemukakan Kepala Badan Keuangan Daerah Bapak Agus Pirngadi sebagai berikut:

"............apakah saudara memberikan insentif khusus pada staf yang berkompeten?.......tidak ada........" ("(Wawancara Senin, 3 Agustus 2020, pukul : 07.15 wib Tempat Kantor Bakeuda). 
Berdasarkan hasil penelitian dapat disimpulkan bahwa Kepala OPD membutuhkan staf yang kompeten untuk melaksanakan kebijakannya, dengan demikian diharapkan disposisi/pesan kebijakan dapat dieksekusi dengan baik. Dan pada sisi lain sebagian besar Kepala OPD tidak memiliki insentif khusus untuk meningkatkan motivasi kerja para stafnya, mereka beranggapan bahwa insentif umum berupa tambahan penghasilan yang diberikan oleh Pemerintah Daerah sudah sangat memadai.

\section{Standar Operasional Prosedur (SOP)}

Hasil penelitian indikator SOP, ada 15 OPD yang dalam pelaksanaan tugasnya tidak selalu memiliki Standar Operasional Prosedur (SOP). Arahan pelaksanaan pekerjaan yang bersifat rutinitas dapat dilakukan dengan perintah lisan dan petunjuk-petunjuk arahan kerja lainnya. Para Kepala OPD menyatakan bahwa mereka memang tidak selalu menyediakan SOP sebagaimana yang dikemukakan oleh Kepala Bakeuda Bapak Agus Pirngadi sebagai berikut :

“.......apakah OPD Saudara memliki panduan-panduan khusus dalam pelaksanaan tugas sehari-hari khususnya pengembangan kompetensi aparatur?.....belum.......... "(Wawancara Senin, 3 Agustus 2020, pukul : 07.15 wib Tempat Kantor Bakeuda).

Pernyataan ini didukung oleh pendapat para Kepala OPD lain, diantaranya Sekretaris Balitbangda Ibu Eka Feriani sebagai berikut :

“.......apakah OPD Saudara memliki panduan-panduan khusus dalam pelaksanaan tugas sehari-hari khususnya pengembangan kompetensi aparatur?.....belum......"(Wawancara Rabu, 24 Juli 2020, puku: 10.15 wib Tempat RSJ).

Dan pendapat Kepala DP3AP2 Ibu Lutpiah sebagaimana pernyataannya sebagai berikut :

“.......apakah OPD Saudara memliki panduan-panduan khusus dalam pelaksanaan tugas sehari-hari khususnya pengembangan kompetensi aparatur?.....tidak ada......" "(Wawancara Selasa, 21 Juli 2020, pukul : 08.18 wib Tempat kantor DP3AP2)

Indikator kedua pada variabel struktur birokrasi adalah fragmentasi yang dimaksudkan untuk upaya penyebaran tanggungjawab kegiatan-kegiatan atau aktivitas-aktivitas pegawai diantara beberapa unit kerja.

\section{Fragmentasi}

Hasil penelitian indikator fragmentasi, ada 9 OPD yang masih menyatakan fragmentasi/pembagian kerja masih belum maksimal. Hal ini disebabkan walaupun struktur sudah disesuaikan dengan kebijakan pemerintah dan masih ada kesan jabatan basah dan jabatan kering. Jabatan basah diasosiasikan kepada jabatan yang banyak kegiatan dan program, sementara jabatan yang kering diasosiasikan dengan jabatan yang kegiatannya sedikit atau bahkan tidak ada. Dan kenyataan ini sulit dilakukan pergeseran-pergeseran karena terkait dengan indikator kinerja jabatan, 
sehingga dengan demikian masih dirasakan kesenjangan antar jabatan, sebagaimana yang disampaikan oleh Kepala Dinas PTSP Bapak Imron Rosyidi yang menyatakan :

“.......apakah dalam penyusuan anggaran OPD saudara membagi staf-staf dalam kelompok sesuai bidangnya? .........dibagi sesuai struktur yang ada, tidak ada yang khusus. ."(Wawancara Selasa, 14 Juli 2020 pukul 16.40 WIB tempat Kantor PTSP).

Pendapat yang senada disampaikan oleh Direktur RSJ Bapak Firmansyah sebagai berikut :

“......apakah dalam penyusuan anggaran OPD saudara membagi staf-staf dalam kelompok sesuai bidangnya? .........tidak......."(Wawancara Rabu, 24 Juli 2020, pukul : 10.10 wib Tempat RSJ).

Dan didukung oleh pendapat-pendapat Kepala DPAD Bapak Syamsurizal yang mengemukakan sebagai berikut:

“......dalam penyusunan anggaran tidak ada pembagian khusus sesuai bidangnya saja....." (Wawancana Senin, 13 Juli 2020 pukul 12.15 WIB tempat Kantor DPAD)

Dan pendapat Kepala DP3AP2 Ibu Lutpiah sebagai berikut :

“......tidak ada pembagian khusus staf terkait penyusunan anggaran........ "(Wawancara Selasa, 21 Juli 2020, pukul : 08.121 wib Tempat kantor DP3AP2)

Dari variabel struktur organisasi, masih ditemui beberapa OPD yang tidak memiliki SOP dalam menjalankan kegiatan-kegiatannya dan sebagian berpendapat bahwa pembagian kewenangan (fragmentasi) belum berjalan optimal, hal ini karena pembagian kewenangan berdasarkan struktur yang ada masih memiliki kesan ada jabatan dengan program dan kegiatan yang banyak, sementara pada sisi lain ada jabatan dengan program dan kegiatan yang sedikit.

\section{Dampak Kebijakan}

Hasil dari penelitian dampak terhadap kebijakan penganggaran pada masing-masing OPD, terlihat jelas bahwa ada 5 OPD yang jumlah personilnya berkesempatan mengikuti pengembangan kompetensi 20\% keatas. Hal ini menunjukkan bahwa di para Kepala OPD benar-benar tidak memperhatikan aspek kompetensi dan kompetensi aparatur bukan merupakan sesuatu yang prioritas. OPD-OPD yang penting dan berpengaruh besar terhadap kinerja instansi Pemerintah Provinsi Jambi seperti Badan Keuangan Daerah, Dinas Kesehatan, Rumah Sakit Jiwa dan Sekretariat DPRD menganggarkan pengembangan kompetensi aparaturnya jauh dibawah kebutuhan seharusnya. Badan Keuangan Daerah memiliki staf yang tersebar diseluruh kabupaten/kota bahkan kecamatan-kecamatan, memerlukan aparatur yang profesional dan mumpuni dalam rangka menjaga kesinambungan pembiayaan pembangunan daerah bersumber Pendapatan Asli Daerah (PAD), selain itu juga diperlukan dalam rangka mengelola administrasi keungan daerah secar baik dam akuntabel yang sudah pasti dibutuhkan aparatur yang berkompeten. Dinas Kesehatan dan Rumah Sakit Jiwa memiliki aparatur yang banyak dan merupakan 
OPD yang berperan besar dalam memberikan pelayanan kesehatan kepada masyarakat. Sekretariat DPRD memiliki peran yang besar dalam rangka menunjang kinerja para pembuat kebijakan DPRD, dengan demikian diharapkan memiliki kinerja yang baik sehingga berperan besar dalam rangka menghasilkan kebijakan publik yang baik bagi masyarakat Provinsi Jambi. Hanya saja peranan besar mereka tidak diiringi dengan kebijakan pengembangan kompetensi aparaturnya secara lebih baik dan merata.

\section{Hasil Temuan Utama}

Hasil temuan utama penelitian ini adalah :

Komunikasi antar stakeholders terkait penganggaran program khususnya penganggaran program pengembangan kompetensi sumber daya aparatur di Lingkup Pemerintah Provinsi Jambi tidak baik, hal ini ditandai 25 Kepala OPD tidak mengetahui aturan Permendagri 33 Tahun 2019 khususnya klausul 0,34\% anggaran untuk dana pengembangan kompetensi aparatur. Sejumlah 67,86\% dari OPD yang diteliti tidak mengikuti perintah aturan Permendagri Nomor 33 Tahun 2019 khususnya klausul 0,34\% anggaran OPD untuk program pengembangan kompetensi sumber daya aparatur dan sebagian besar Kepala OPD mengatakan pengembangan kompetensi aparatur bukan prioritas meraka. Sebanyak 39,39\% OPD mengatakan bahwa pengangkatan birokrat di OPD mereka tidak sesuai dengan yang mereka harapkan baik dari sisi kuantitasnya maupun kualitasnya. Sekitar 45,45\% OPD tidak memiliki dan/atau tidak lengkap Standar Operasional Prosedur (SOP) dalam melaksanakan tugas program dan kegiatannya.

Dampak dari tidak terpenuhinya ketentuan prosentase anggaran pengembangan kompetensi sumber daya aparatur pada masing-masing OPD di Lingkup Pemerintah Provinsi Jambi adalah hanya sekitar 15 \% PNS Lingkup Pemerintah Provinsi Jambi yang memperoleh kesempatan untuk mengembangkan kompetensinya.

\section{KESIMPULAN DAN SARAN}

Komunikasi yang dilakukan dalam proses implementasi kebijakan anggaran pengembangan kompetensi aparatur tidak baik sebagaimana mestinya, hal ini ditandai dengan tidak terjadinya transmisi aturan Permendagri Nomor 33 Tahun 2019, khususnya klausul 0,34\% anggaran pengembangan kompetensi aparatur.

Kemampuan sumber daya dalam proses implementasi kebijakan anggaran pengembangan kompetensi aparatur belum berjalan optimal, hal ini ditandai dengan masih ditemui 17 OPD yang tidak memiliki staf yang memadai untuk menjalankan program dan kegiatannya, baik dari sisi jumlah staf yang masih kurang maupun kompetensi staf yang masih perlu ditingkatkan. Disposisi dalam proses implementasi kebijakan anggaran pengembangan kompetensi aparatur belum berjalan baik, hal ini 
ditandai dengan masih adanya 13 OPD yang mengeluhkan bahwa pengangkatan birokrat masih belum sesuai dengan harapan mereka. Struktur birokrasi dalam proses implementasi kebijakan anggaran pengembangan kompetensi aparatur belum optimal, hal ini ditandai dengan sebanyak 15 OPD belum memiliki semua SOP yang terkait dengan pelaksanaan program dan kegiatan di OPD masing-masing.

Komunikasi yang tidak baik, sumber daya yang terbatas, disposisi yang tidak sesuai harapan dan struktur birokrasi yang belum memadai, serta dikombinasi anggaran pengembangan kompetensi aparatur yang minim akan berimplikasi kepada kesempatan aparatur untuk memperoleh peningkatan kompetensinya menjadi terhambat, dan akan berimplikasi juga kepada terhambatnya peningkatan kinerja organisasi.

\section{DAFTAR PUSTAKA}

Agostiono, 2010, Implementasi Kebijakan Publik Model Van Meter dan Van Horn, Rajawali Press, Jakarta,

Agustino, L., 2012, Dasar-Dasar Kebijakan Publik, Penerbit Alfabeta, Bandung.

Arikunto S., 2006, Prosedur Penelitian Suatu Pendekatan Praktik, Penerbit Rineka Cipta, Jakarta

Badrun Kartowagiran (2013). Optimalisasi Evaluasi Pembelajaran Teknik Mesin Melalui Logic Model Untuk Meningkatkan Soft Skill Lulusan. Yogyakarta : Pidato Pengukuhan Guru Besar dalam Bidang Ilmu Evaluasi Pembelajaran Teknik Mesin Pada Fakultas Teknik Universitas Negeri Yogyakarta tanggal 10 Juni 2013. Hadi, Samsul dkk. (2011). Metode Riset Evaluasi. Yogyakarta : Lakbang Grafika Howlett, Michael and M. Ramesh. 1995. Studying Public Policy: Policy Cycles and Policy Subsystem, Oxford University Press, Oxford

Kellogg Foundation (2017). The Step By Step Guide To Evaluation How To Become Savoy Evaluation Consumers.

Kennett, Patricia (2008). Governance, Globalization and Public Policy. Massachusetts USA: Edward Elgar Publishing, Inc.

Morra-Imas, Linda G. \& Rist, Ray C., (2009). The Road Results To : Designing And Conducting Effective Development Evaluations. Washington DC-US : The World Bank

Muliati (2007). Evaluasi Program Pendidikan Sistem Ganda. Jakarta: Dipertahankan di hadapan Sidang Senat Guru Besar Universitas Negeri Jakarta dalam Rangka Promosi Doktor

Perkalan Nomor 4 Tahun 2017 tentang Pedoman Pelaksanaan Orasi Ilmiah Widyaiswara, Jakarta

Purwanto E. A dan Sulistyastuti, D. R, 2012, Implementasi Kebijakan Publik Konsep dan Aplikasinya di Indonesia, Penerbit Gava Medis, Yogyakarta. 
Stufflebeam, Daniel L. \& Coryn, Chris L. S. (2014). Evaluation Theory, Models, And Applications. $2^{\text {nd }}$ edition. San Francisco-US : Jossey-Bass.

Suharsimi, Arikunto. \& Cepi Safruddin A.J. (2010). Evaluasi Program Pendidikan : Pedoman Teoritis Praktis Bagi Mahasiswa dan Praktisi Pendidikan (Cetakan ke 4). Jakarta : Bumi Aksara

Suharsimi, Arikunto. (2012). Dasar-Dasar Evaluasi Pendidikan (Edisi 2). Jakarta : Bumi Aksara.

Susskind, Lawrence (2006). Arguing, Bargaining, And Getting Agreement dalam Moran, Michael (editor). The Oxford Handbook Of Public Policy. New York: Oxford University Press Inc.

Suwitri, Sri, 2008, Konsep Dasar Kebijakan Publik, Badan Penerbit Universitas Diponegoro, Semarang.

Usman, 2004, Pembangunan dan Pemberdayaan Masyarakat, Pustaka Pelajar, Yogyakarta

Wahab, Solichin Abdul, 2002, Analisis Kebijaksanaan: dari Formulasi ke Implementasi Kebijaksanaan Negara, Sinar Grafika, Jakarta.

Wibawa S, 2005, Peluang Penerapan New Public Management Untuk Kabupaten di Indonesia, Gadjah Mada University Press, Yogyakarta

Winarno, Budi, 2008, Kebijakan Publik: Teori dan Proses, PT. Buku Kita, Jakarta, 